\title{
Analisis Warna Lokal Sunda dalam Kumpulan Cerpen "Dua Orang Dukun dan Cerita Pendek Sunda Lainnya” Karya Ajip Rosidi
}

\author{
Pipik Asteka ${ }^{1)}$, Deden Sutrisna ${ }^{2)}$ \\ Pipikasteka86@gmail.com ${ }^{1)}$, dedensutrisna@gmail.com ${ }^{2)}$ \\ PBI, FKIP Universitas Majalengka ${ }^{12)}$
}

\begin{abstract}
Abstrak. Warna lokal adalah warisan leluhur yang didasarkan pada hasil pengamatan terhadap alam dan lingkungan sekitar. Warisan ini amat disayangkan jika tidak diketahui oleh generasi muda. Oleh karena itu, melalui sastra diharapkan siswa bisa mengetahui warna lokal yang ada di daerahnya bahkan warna lokal yang ada di daerah lain sehingga mereka bisa menjadi manusia yang bijak. Penelitian ini mencoba menyajikan warna lokal Sunda sebagai bahan ajar apresiasi sastra bermuatan karakter di kelas XI SMA. Pemilihan warna lokal Sunda adalah sebagai alternatif bahan ajar yang menumbuhkan kesadaran pentingnya identitas lokal dalam mempelajari sastra karena dari identitas lokal itu akan muncul karakter yang membangun mental siswa. Penelitian ini akan mendeskripsikan warna lokal Sunda yang muncul dalam kumpulan cerpen Dua Orang Dukun dan Cerita Pendek Sunda Lainnya ditinjau dari lima sikap, yaitu religius, kepribadian, sosial, kekeluargaan, dan lingkungan.
\end{abstract}

Kata kunci : warna lokal sunda, kumpulan cerpen, dua orang dukun dan cerita pendek sunda lainnya.

\section{Pendahuluan}

Kumpulan Cerpen Dua Orang Dukun dan Cerita Pendek Sunda Lainnya merupakan kumpulan cerpen karya sepuluh orang pengarang Sunda yang diterjemahkan oleh Ajip Rosidi. Kumpulan cerpen Dua Orang Dukun dan Cerita Pendek Sunda Lainnya secara refresentatif mewakili cerpen-cerpen Sunda pada umumnya karena disajikan dengan tema yang beragam. Kumpulan terjemahan cerpen dari bahasa Sunda ini dianggap sebagai karya sastra yang sedikit banyak mencerminkan lingkungan masyarakat Sunda baik berupa sikap, pandangan, identitas dan kemampuan masyarakat Sunda yang berada di provinsi Jawa Barat.

Penelitian ini berorientasi kearifan budaya lokal atau warna lokal yang menjadi domisili peneliti saat ini, yakni tanah Sunda. Warna lokal sunda yang merupakan ciri khas, budaya, dan kekhasan urang Sunda baik warna lokal Sunda masa lalu dan masa kini, wajib diperkenalkan kepada siswa agar mereka dapat memelihara dan bertindak sesuai dengan akar budaya sunda yang sesungguhnya, di mana sangat kaya dengan karakter positif.

Analisis ini mencakup lima hal yang menjadi penanda karya sastra sebagai media pembentukan karakter, yaitu ada tidaknya aspek (1) nilai keindahan, keelokan, kebagusan, kenikmatan, dan keterpanaan; (2) nilai kemanusiaan, menjunjung harkat dan martabat manusia, serta menggambarkan situasi dan kondisi manusia dalam menghadapi berbagai masalah; (3) mengandung nilai etis dan moral dalam karya sastra mengacu pada pengalaman manusia dalam bersikap dan bertindak, melaksanakan yang benar dan yang salah, serta bagaimana seharusnya kewajiban dan tanggung jawab manusia dilakukan; dan (4) genre sastra yang menyajikan pengalaman spiritual dan transendent Saryono (2009). 
Penelitian ini menggunakan metode deskriptif-analisis, data terurai dalam bentuk katakata, bukan dalam bentuk angka. Semi (2012) menjelaskan bahwa dalam penelitian yang bersifat deskriptif, penulis berupaya menemukan pandangan, membuat kesimpulan dan memberikan rumusan-rumusan yang diarahkan kepada pemerkayaan hasil kajian lewat kata-kata. Jadi, penelitian jenis ini lebih mengutamakan kedalaman penghayatan terhadap interaksi antar konsep yang sedang dikaji secara empiris.

Metode deskriptif-analisis ini digunakan dalam kegiatan menganalisis cerpen. Data yang terkumpul kemudian diseleksi, dilakukan pengkajian, dan disimpulkan. Selanjutnya hasil kesimpulan itu dideskripsikan. Analisis data dilakukan dengan mengetengahkan fakta yang berhubungan dengan warna lokal Sunda yang terdapat dalam cerpen yang menjadi objek penelitian.

Lembar analisis dalam penelitian ini berisi hal-hal mengenai data cerpen dan pola analisis. Analisis data dari segi warna lokal sunda yang diambil meliputi (1) sikap tokoh, (2) perilaku tokoh, dan (3) tutur bahasa yang diucapkan tokoh. Analisis data yang diambil terdapat dalam setiap wujud warna lokal sunda, yaitu

a. deskripsi warna lokal sunda berupa hubungan manusia dengan Tuhannya (sikap religius);

b. deskripsi warna lokal sunda berupa hubungan manusia dengan dirinya (kepribadian);

c. deskripsi warna lokal sunda berupa hubungan manusia dengan sesamanya (sosial);

d. deskripsi warna lokal sunda berupa hubungan manusia dengan keluarganya; dan

e. deskripsi nilai budaya dalam hubungan manusia dengan alamnya.

\section{Hasil dan Pembahasan}

\section{A. Warna lokal Sunda dalam Kumpulan Cerpen Dua Orang Dukun dan Cerita Pendek Sunda Lainnya ditinjau dari lima sikap.}

Warna lokal Sunda yang muncul dalam cerpen Dua Orang Dukun dan Cerita Pendek Sunda Lainnya sangat mewakili karakter dan kebudayaan masyarakat Sunda yang tinggal di lingkungan pedesaan dan tidak sedikit masyarakat Sunda yang tinggal di perkotaan masih sangat kental dengan karakter positif yang harus dipertahankan oleh generasi muda Sunda saat ini yang sangat rentan dengan hal negatif, baik berupa pengikisan moral dan lupa akan akar keturunan yang dahulunya menjunjung tinggi nilai warna lokal. Warna lokal Sunda tersebut dapat tergambar dengan jelas pada deskripsi di bawah ini.

\section{Sikap Religius}

Warna lokal berupa nilai religius pada suku Sunda terdapat pada keyakinan mereka bahwa alam semesta dan seisinya ini ada yang menciptakan. Oleh karena itu, dalam keseharian dan aktivitas sehari-hari suku Sunda tidak melupakan interaksi dengan penciptanya. Suku Sunda dikenal sebagai suku yang taat beragama. Pada cerpen berjudul Mencari misalnya, unsur religius tokoh utama pengarang paparkan dengan cara analitik. Tokoh utama dalam cerpen ini bernama Andria lelaki urban atau perkotaan yang bosan dengan rutinitas keseharian masyarakat kota. Dia memutuskan untuk cuti dari pekerjaannya dan berlibur tanpa tujuan. Di antara barang-barang yang dia bawa selama liburan tersebut terdapat sarung pelekat dan peci. Hal ini cukup menimbulkan kesan bahwa suku sunda adalah suku dengan ketaatan atau religiutas yang tinggi karena di mana 
pun mereka berada mereka tidak melupakan kewajiban beribadah.

Cerpen berjudul Tersesat menampilkan tokoh utama Agus Naim seorang pemuda yang memutuskan untuk berkelana mencari ketenangan batin karena kekasih pujaan hatinya menikah dengan lelaki lain. Awalnya dia berkelana dengan tujuan untuk menjadi santri di Kiai Mungkallonjong. Beberapa dialog menunjukkan bahwa Agus Naim seorang yang memiliki pengetahuan agama yang luas.

\section{Kepribadian}

Warna lokal Sunda yang menjadi pembeda antara suku Sunda dengan suku lainnya ada pada kepribadian khas yang masih terjaga hingga saat ini. Kepribadian itu di antaranya pintar, periang, sopan santun, lemah lembut, menjunjung tinggi adat istiadat, dan sangat menghormati orang tua.

\section{a) Pintar}

Nenek moyang orang Sunda dikenal sebagai orang yang pintar dalam mengelola alam. Mereka memiliki sistem tata kelola alam sehingga alam di Priangan masih terjaga hingga saat ini.

\section{b) Periang}

Suku Sunda dikenal periang dan sangat humoris. Beberapa cerpen yang terdapat dalam Cerpen mencerminkan kepribadian orang Sunda yang suka bercanda atau menyenangi hal-hal yang menimbulkan kelucuan.

Cerpen berjudul Dua Orang Dukun dan Cerita Pendek Sunda Lainnya, meskipun bertemakan kritik sosial dengan gaya tulisan satire (sindiran). Namun, unsur humornya sangat terlihat sekali. Dua orang tokoh utama dalam cerpen ini, yaitu Mak Ikrem dan Mak Copet diceritakan sebagai dua orang dukun yang tidak pernah akur. Pengarang menyelipkan unsur humor pada perdebatan mereka berdua tentang diagnosis penyakit yang diderita oleh Nyi Encih. Pada cerpen tersebut kita bisa menyimpulkan bahwa orang sunda meskipun dalam keadaan marah sekalipun tidak mengurangi kepribadian mereka yang suka menghibur atau humoris.

\section{c) Sopan santun}

Kepribadian sopan santun, dan ramah-tamah terlihat pada cerpen yang berjudul Mencari. Salah satu tokoh dalam cerpen ini, yaitu Nyi Warsih digambarkan secara dramatik sebagai gadis desa yang sopan.

"Nyi-nyi! Saya menegurnya. "Rumah Nyaikah ini?"

"sumuhun" sahutnya sambil terus masuk ke dapur.

Tak lama kemudian, pintu dari rumah ke serambi dibuka.

Adapun kepribadian ramah-tamah ditunjukkan oleh Bapak dari Nyi Karsih, yaitu Bapak Alwasim.

"Bapak maafkan saya telah berbuat lancang, memberanikan diri naik rumah orang selagi tak ada yang empunya...."

\section{d) Lemah lembut}

Salah satu kepribadian orang sunda adalah lemah lembut saat berbicara terutama kepada seseorang yang lebih tua, suami saat berbicara dengan istrinya, dan lain-lain. 
Cerpen yang berjudul Pertemuan di Kuburan misalnya terdapat dialog suami-istri, yaitu Emur dan Juragan Sukarta

"Silakan saja engkang ke sana sendiri. Biarlah saya ikut ke makan bersama Bi Icih."

"Bagaimana pula itu; kan kita harus berdua, karena tamu yang datang pun tidak hanya laki-laki saja.”

"Mengapa kemarin Engkang berjanji sembarangan?"

"Bukan berjanji sembarangan, tapi lupa. Mengapa pula kemarin Emur tak kasih ingat"

Dari dialog di atas terlihat bahwa sebetulnya Emur sangat emosional. Namun, juragan Sukarta tidak terpancing. Nada bicara juragan Sukarta menunjukkan sikap lemah lembut terhadap istri.

\section{e) Menjunjung tinggi adat}

Suku Sunda sangat menjunjung tinggi adat istiadat. Bagi mereka meskipun nenek moyang mereka sudah tidak ada, tetapi nilai-nilai warisan dalam bentuk adat istiadat dan tradisi harus tetap ada. Suku Sunda menjaga dan menjunjung tinggi adat baik berupa norma atau kebiasaan maupun kesenian karena semuanya memiliki nilai filosofis yang jika dipertahankan akan mendatangkan manfaat. Salah satu contoh kesenian tersebut adalah Doger Karawang. Pada cerpen yang berjudul Doger Karawang, diceritakan bagaimana perjuangan kelompok musik doger yang harus berjalan kaki keliling desa untuk menjemput bola barangkali ada seseorang yang hendak menanggap doger. Walaupun imbalan atau upah berupa makanan saja mereka sudah siap menampilkan kesenian khas Karawang tersebut.

\section{f) Sangat menghormati orang tua}

Suku Sunda dikenal sebagai suku yang sangat menghormati orang tua, meskipun orang tua tersebut sudah meninggal. Mereka menganggap orang tua adalah orang yang berjasa dalam kehidupan oleh karena itu meskipun mereka sudah meninggal nilai-nilai warisan yang ditinggalkan tetap ada. Sebagai bentuk ucapan terima kasih saat lebaran orang Sunda akan berkunjung ke makam leluhurnya untuk berdoa.

"Dari kawan-kawan kita tidak bakal doraka, lain dengan orang tua sendiri."

"Kukira bahkan dari orang tua sendiri kita lebih mudah mendapatkan maaf daripada dari kawan-kawan yang belum tentu mau kasih maaf."

"Peduli apa! Tapi saya bilang, orang tua sendiri lebih penting, nanti doraka kalau dinomorduakan."

\section{Sosial}

Suku Sunda memiliki sistem sosial yang mengatur pergaulan antar masyarakat. Cerpen yang berjudul Mencari, kita akan menjumpai bagaimana sistem sosial yang menjadi warna lokal Sunda di antaranya jarak antar rumah di daerah Sunda yang berdekatan. Selain itu, tidak adanya pagar rumah membuat siapa pun bisa masuk untuk bertamu.

“.....Maka saya pun berkeliling dari rumah yang satu ke rumah yang lain, mengharapharap mungkin ada yang terbuka atau bersua kembali gadis tadi. Akhirnya naiklah saya duduk di serambi sebuah rumah, bersandar pada tiang, entah ke arah mana. Rumah yang saya naiki adalah yang terbesar."

Tema sosial yang diangkat dalam kumpulan cerpen Dua Orang Dukun dan Cerita Pendek Sunda lainnya cukup beragam. Namun, umumnya mengarah pada masalah-masalah sosial yang 
ada di masyarakat, seperti kritik terhadap berbagai keadaan, kesenjangan, bahkan sindiransindiran halus.

Cerpen berjudul Dua Orang Dukun Misalnya, ini sebetulnya kritik sosial terhadap masyarakat sunda yang religius, tetapi masih mempercayai praktik-praktik perdukunan yang berbau kemusrikan. Pengarang memaparkan secara analitik sindirannya sebagai berikut.

"Mereka pun tersohor pula sebagai dukun yang pandai menaklukkan segala bangsa demit, setan, onom, genderewo, dan sejenisnya. Werejit, teluh, racun dan jaran guyang, menurut sebagian orang yang berkata, semuanya sudah ada dalam genggaman kedua dukun tersebut."

Akhir dari cerpen Dua Orang Dukun menjadi inti kritikan pengarang terhadap mereka yang masih mempercayai dukun. Ternyata penyakit aneh yang dialami Nyi Karsih, sebelumnya diagnosis Mak Ikrem yang mengatakan Nyi Karsih sakit Kalingsir dan dibantah oleh Mak Copet Nyi Karsih sakit Gregesan, adalah sakit menstruasi.

"Ketika ia masuk, Nyi Encih nampak sedang duduk sambil tertawa jua, penyakitnya mendadak sembuh, yaitu....darah kotor bulanannya tumpah keluar karena perutnya dipukul-pukul dan diguncang-guncangkan oleh ibu dukun yang sedang murka."

\section{Kekeluargaan}

Salah satu warna lokal Sunda yang menjadi ciri khas suku Sunda adalah sistem kekerabatan atau kekeluargaan. Suku Sunda senang sekali menghubungkan silsilah keluarga. Menyambung silaturahmi yang terputus karena regenerasi akan mereka sambung kembali sebagai upaya agar leluhur mereka senang. Memutuskan ikatan kekeluargaan dianggap sebagai perbuatan yang akan memunculkan malah petaka dikemudian hari.

Beberapa cerpen dalam buku ini bertemakan kekeluargaan seperti yang terdapat dalam cerpen berjudul Silsilah Keluarga. Cerpen ini menceritakan tentang orang Sunda yang mencoba mencari silsilah keluarga yang terputus.

"saya temenung...kubaca sekali lagi, lalu termenung pula. Kuperhatikan kembali alamatnya barangkali keliru. Nama dan jabatannya tertera dengan jelas. Bingung saya tidak, malah merasa gembira ada juga orang yang menganggap keluarga. Tapi saya tak tahu bagaimana silsilahnya. Keluarga dari mana? Tanya hatiku. Dari ayah atau dari ibuku? Tapi ketika ku pikir-pikir lagi, baik dari pihak ibu ataupun ayah, masih saudaraku juga, keduanya sama."

Pertemuan di Kuburan, Cerpen ini berkisah tentang suasana lebaran yang dihadapi oleh suami istri, yaitu Juragan Sukarta dan istrinya Emur. Pengarang berhasil memunculkan kesan mendalam suasana lebaran.

\section{Lingkungan}

Suku Sunda memiliki pengetahuan tentang pengelolaan lingkungan yang harmonis dan selaras. Falsafah pengelolaan alam ini dikenal dengan sebutan Sunda Wiwitan. Sunda Wiwitan adalah sistem ajaran pengelolaan lingkungan yang ada di tanah sunda sejak dahulu. Pada cerpen berjudul Mencari dijumpai warna lokal sunda berupa deskripsi lingkungan khas daerah suku Sunda.

“Alangkah luas! Alangkah luas alam menerawang, tak seperti pemandangan dalam kota yang terasa sempit, sesak-pengap, pendek-pandang. Nun jauh di sana, terhalang oleh punggung bukit, nampak jauh meraih langit, gunung yang membiru. Pematang sawah melingkar-lingkar dan di atasnya bercongakan bambu penambat kacang dan cipir." 
Cerpen yang berjudul mencari dapat dilihat bagaimana masyarakat Sunda mengelola alam sekitar, memanfaatkannya sebagai mata pencaharian, tetapi tidak mengeksploitasinya secara berlebihan. Pandangan tentang pengelolaan alam yang selaras ini membuat warna lokal Sunda patut dilestarikan. Hal ini juga yang dideskripsikan dalam cerpen berjudul Mencari ini begitu menarik untuk dibaca.

\section{Analisis Data}

Analisis data yang akan disajikan dengan pola kartu data di bawah ini akan diambil dari segi warna lokal sunda yang ada dalam kumpulan cerpen Dua Orang Dukun dan Cerita Pendek Sunda Lainnya. Data yang diambil meliputi sikap tokoh, perilaku tokoh, dan tutur bahasa yang diucapkan tokoh dari masing-masing cerpen yang diambil sebagai sampel dari kumpulan cerpen dimaksud. Analisis data yang diambil dalam setiap wujud warna lokal sunda, yaitu deskripsi warna lokal sunda berupa hubungan manusia dengan Tuhannya (sikap religius), deskripsi warna lokal sunda berupa hubungan manusia dengan dirinya (kepribadian), deskripsi warna lokal sunda berupa hubungan manusia dengan sesamanya (sosial), deskripsi warna lokal sunda berupa hubungan manusia dengan keluarganya, deskripsi nilai budaya dalam hubungan manusia dengan alamnya.

\section{Tabel 1}

\section{Analisis Data Warna Lokal Sunda}

\begin{tabular}{|c|c|c|c|}
\hline $\begin{array}{l}\text { No } \\
\text { Data }\end{array}$ & Analisis Data & Cerpen & Simpulan \\
\hline 1 & $\begin{array}{l}\text { Dialog Agus Naim dan Tukang Warung } \\
\text { mencerminkan pandangan ketuhanan berupa } \\
\text { ketaatan dalam menjalankan ibadah }\end{array}$ & Tersesat & $\begin{array}{c}\text { Warna lokal } \\
\text { religius }\end{array}$ \\
\hline 2 & $\begin{array}{l}\text { Tokoh Agus Naim diceritakan sebagai orang yang } \\
\text { taat menjalankan perintah salat }\end{array}$ & Tersesat & $\begin{array}{l}\text { Warna lokal } \\
\text { religius }\end{array}$ \\
\hline 3 & $\begin{array}{l}\text { Tekad tokoh Agus Naim untuk menjadi santri } \\
\text { menunjukkan bahwa ia ingin memperdalam ilmu } \\
\text { agama }\end{array}$ & Tersesat & $\begin{array}{c}\text { Warna lokal } \\
\text { religius }\end{array}$ \\
\hline 4 & $\begin{array}{l}\text { Niat tokoh Agus Naim belajar mengaji } \\
\text { menunjukkan bahwa dia seorang yang serius ingin } \\
\text { memperdalam ilmu agama }\end{array}$ & Tersesat & Religius \\
\hline 5 & $\begin{array}{l}\text { Tokoh Emang pemilik warung mencerminkan } \\
\text { seseorang yang belum menyadari pentingnya } \\
\text { beribadah sebagai bentuk ketaatan dalam } \\
\text { menjalankan perintah }\end{array}$ & Tersesat & Religius \\
\hline 6 & $\begin{array}{l}\text { Seseorang yang beriman ketika dia salah jalan } \\
\text { menempuh jalan kesesatan maka ilmu agamanya } \\
\text { akan hilang, seperti Agus Naim dia berguru ilmu } \\
\text { harimau (ilmu hitam) sehingga pengetahuan agama } \\
\text { yang dia miliki menjadi hilang }\end{array}$ & Tersesat & Religius \\
\hline 7 & $\begin{array}{l}\text { Pujian adalah sejenis sholawat yang biasa } \\
\text { dilakukan sebelum salat. Terlihat dari cerpen } \\
\text { tersebut tokoh Agus Naim bertaubat dan menyadari }\end{array}$ & Tersesat & Religius \\
\hline
\end{tabular}


kesalahannya dalam menuntut ilmu karena ilmu yang dia pelajari adalah ilmu maung/macam dan termasuk ilmu hitam.

8 Tokoh embi/ibu menunjukkan rasa keterkejutan dengan menyebut asma Allah ini menunjukkan sikap ingat kepada sang pencipta alam semesta.

9 Emur menunjukkan rasa terkejutnya dengan menyebut pencipta-Nya dan memohon ampun kepada Allah.

10 Ketika berziarah kubur di sunahkan untuk mendoakan ahli kubur ini juga yang dilakukan juragan Adjun dan keluarganya

11 Sarung, pelekat, dan peci adalah kelengkapan salat

12 Orang yang beriman akan mengucapkan kata Insya Allah sebagai bentuk ucapan saat berjanji

13 Tokoh utama, Andria, mengucapkan Alhamdulillah sebagai bentuk rasa sukur terhadap apapun takdir Allah Swt, meskipun dia belum ditakdirkan menikah

14 Tokoh Aku adalah orang taat menjalankan perintah shalat, meskipun sedang berada di rumah kerabat.

15 Sebagai seorang beriman tokoh aku akhirnya bisa memaafkan Abidin dengan mengikhlaskan apa yang sudah terjadi di antara mereka

16 Insya Allah diucapkan untuk meyakinkan bahwa apa yang diperbuat atau lakukan sudah sesuai

17 Tokoh Aku tidak terlena dengan obrolan dengan kerabatnya, dia tetap mengutamakan salat tepat waktu ini merupakan ciri orang yang taat dalam beragama

18 Langgar adalah sejenis musholah. Sebagai seorang laki-laki wajib hukumnya beribadah di langgar. Hal ini bertujuan untuk mempererat tali silaturahmi.

19 Tokoh Aku menyadari bahwa takdir yang dialaminya merupakan ketetapan dari yang Mahakuasa

20 Tokoh Aku menyadari sesudah kesenangan akan tiba saatnya kesedihan begitupun sebaliknya segalanya harus dihadapi dengan penuh kesabaran.

21 Jihad artinya berjuang di jalan Allah

22 Dalam keadaan susah tokoh Aku tetap menjalankan shalat meskipun dia merasa shalatnya tidak sah

23 Masjid selain sebagai tempat ibadah juga berfungsi sebagai sentra ekonomi umat

24 Mesjid selain sebagai tempat ibadah juga bisa menjadi tempat singgah seperti yang dilakukan tokoh Aku
Pertemuan
di

Kuburan

Pertemuan Religius di

Kuburan

Pertemuan $d i$

Kuburan

Mencari

Religius

Mencari

Religius

Mencari religius

Silsilah

Religius

Keluarga

Silsilah

Religius

Keluarga

Silsilah

Keluarga

Silsilah

Keluarga

Silsilah

religius

Keluarga

Silsilah

Keluarga

Religius

Silsilah

Religius

Keluarga

Harapan Religius

Harapan Religius

Harapan

Religius

Harapan Religius 
25 Meskipun dalam keadaan sakit borok, tokoh Aku tidak melupakan kewajibannya shalat berjamaah di langgar

26 Dalam ajaran agama islam sesama umat wajib tolong menolong

27 Ciri khas orang yang berilmu dia tidak akan berhenti belajar dan menambah ilmu

28 Dari dialog yang diucapkan suami Emur atau Juragan Sukarta termasuk orang yang pintar dalam upayanya mempengaruhi/membujuk istrinya

29 Argumen yang dikemukakan Sukarta menunjukkan kepintarannya

30 Keberhasilan Agus Naim melalui ritual ngelmu kebal menunjukkan ia seorang yang pintar

31 Emur menjahit sendiri pakaian yang akan dikenakannya di hari lebaran ini menunjukkan dia kreatif.

32 Nyi Warsih kreatif memanfaatkan apa yang ada di lingkungan

33 Kreativitas yang dilakukan Andria didasari rasa penasaran terhadap wanita yang dijumpainya di ladang

34 Tukang obat keliling dikenal dengan berbagai kreativitasnya ketika memasarkan obatnya

35 Tokoh aku dan tokoh lainnya yang tergabung dalam group kesenian Doger Karawang merupakan orang kreatif dalam berkesenian

36 Mak Ikrem dan Mak Copet diceritakan sebagai dua orang dukun yang tidak pernah akur. Pengarang menyelipkan unsur humor pada perdebatan mereka berdua tentang diagnosis penyakit yang diderita oleh Nyi Encih. Dari sini kita bisa menyimpulkan bahwa orang sunda meskipun dalam keadaan marah sekalipun tidak mengurangi kepribadian mereka yang suka menghibur atau humoris

37 Orang Sunda meskipun sedang marah, tetapi tidak menyeramkan malah sebaliknya lucu dan menimbulkan gelak tawa orang yang mendengarnya

38 Suasana lebaran membuat Neng Emur, Neng Icoh, dan Eroh riang gembira

39 Lazimnya kakak-beradik suka saling mengejek yang terkadang menimbulkan kelucuan

40 Suasana lebaran yang ramai orang membuat Neng Emur, Neng Cioh, dan Neng Ento menjadikan orang-orang yang mereka temui di jalan sebagai bahan candaan.
Harapan Religius

Harapan Religius

Harapan Kepribadian pintar

Harapan Pintar

Harapan Pintar

Harapan Pintar

Pertemuan Kepribadian

Kuburan

Mencari Kreatif

Mencari Kreatif

harapan Kreatif

Doger Kreatif

Karawang

Dua

Periang

Orang

Dukun

Dua

Periang

Orang

Dukun

Dua

Periang

Orang

Dukun

Dua

Orang

Dukun

Dua

Orang

Dukun 
41 Karakteristik remaja yang beranjak dewasa seperti

Dua

Periang

Neng Cioh dan Neng Ento senang sekali bercanda

Orang

Dukun

42 Orang Sunda meskipun dalam keadaan sakit tetap

Harapan

Periang

tidak kehilangan sifat periang

43 pada saat menghubungkan silsilah kekerabatan ternyata ada kekeliruan dari apa yang disampaikan oleh tokoh Emang. Sikap jujur yang dimiliki tokoh

Silsilah

Jujur

Keluarga aku patut diteladani karena meskipun berdampak pada orang-orang yang tidak lagi mengakui tokoh aku sebagai kerabat

44 Neng Emur mengakui kesalahannya di masa lalu pada saat menelantarkan anaknya

$\begin{array}{cc}\begin{array}{c}\text { Pertemuan } \\ \text { di }\end{array} & \text { Jujur } \\ \text { Kuburan } & \\ \text { Mencari } & \text { Jujur } \\ \text { tersesat } & \text { Jujur }\end{array}$

46 Agus Naim tidak malu berterus terang mengakui bahwa dirinya orang yang tersesat

47 Meminta izin tuan rumah untuk masuk kamarnya adalah sebuah sikap yang patut diteladani mengingat kamar tidur adalah ruangan yang memiliki privasi tinggi.

48 Sikap sopan santun ketika ada tamu, yaitu dengan segera membukakan pintu

49 Saat kerabat yang lebih tua berkunjung sikap salaman kita harus menunjukkan sikap menghormati

50 Menyembah lazim dilakukan seseorang sebagai bentuk penghormatan kepada raja

51 Bersalaman dengan berlutut lazim dikenal sebagai sungkeman, yaitu bentuk penghormatan terhadap orang tua

52 Sikap menghormati orang yang lebih tua

Dua

Sopan Santun

Orang

Dukun

Mencari Sopan santun

Pertemuan Sopan Santun di

Kuburan

Mencari

Sopan santun

Silsilah

Sopan santun

Keluarga

Silsilah Sopan santun

keluaga

Dua

Ramah-tamah

Orang

Dukun

54 Menyuguhkan hidangan sebagai penghormatan terhadap tamu

55 Mayoritas suku Sunda terutama yang masih bercorak tradisional menganggap bahwa tamu ibarat raja yang membawa keberuntungan. Oleh karena itu mereka akan menyuguhkan hidangan terbaik.

56 Mayoritas suku Sunda terutama yang masih

Pertemuan

Ramah tamah di kuburan

Silsilah

Kekeluargaan

Keluarga

Mencari Kekeluargaan bercorak tradisional menganggap bahwa tamu ibarat raja yang membawa keberuntungan. Oleh karena itu mereka akan menyuguhkan hidangan 
terbaik.

57 Mayoritas suku Sunda terutama yang masih

Mencari

Kekeluargaan

bercorak tradisional menganggap bahwa tamu ibarat raja yang membawa keberuntungan. Oleh karena itu mereka akan menyuguhkan hidangan terbaik.

58 Mayoritas suku Sunda terutama yang masih bercorak tradisional menganggap bahwa tamu ibarat raja yang membawa keberuntungan. Oleh karena itu mereka akan menyuguhkan hidangan terbaik.

59 Mayoritas suku Sunda terutama yang masih bercorak tradisional menganggap bahwa tamu ibarat raja yang membawa keberuntungan. Oleh karena itu mereka akan menyuguhkan hidangan terbaik.

60 Mayoritas suku Sunda terutama yang masih bercorak tradisional menganggap bahwa tamu ibarat raja yang membawa keberuntungan. Oleh karena itu mereka akan menyuguhkan hidangan terbaik.

61 Mayoritas suku Sunda terutama yang masih bercorak tradisional menganggap bahwa tamu ibarat raja yang membawa keberuntungan. Oleh karena itu mereka akan menyuguhkan hidangan terbaik.

62 Ini merupakan kritik sosial terhadap masyarakat yang masih mempercayai dukun

63 Sikap peduli terhadap penderitaan orang lain

64 Tradisi atau kebiasaan saling mengunjungi saat lebaran untuk bersilaturahmi

65 Suku sunda memiliki sistem sosial yang mengatur pergaulan antar masyarakat. Pada cerpen yang berjudul Mencari, kita akan menjumpai bagaimana sistem sosial yang menjadi warna lokal sunda di antaranya jarak antar rumah di daerah sunda yang berdekatan. Selain itu, tidak adanya pagar rumah membuat siapa pun bisa masuk untuk bertamu.

66 Kritik sosial terhadap rasa persaudaraan dan diskriminasi pada yang bukan saudara

67 Suku sunda senang sekali menghubungkan kekerabatan atau persaudaraan baik melalui silsilah maupun asal tempat

68 Saat ada anggota keluarga yang sakit maka anggota keluarga yang lain akan datang ini merupakan sikap guyub

Dua orang

Dukun

Pertemuan $d i$

Kuburan

Pertemuan di kuburan mencari

Silsilah

Keluarga

Silsilah

Keluarga

Dua

Orang

Dukun
Sosial

Sosial

Sosial

Sosial

Sosial

Kekeluargaan

Pertemuan

Kekeluargaan 
akan mengunjungi kerabat atau keluarga yang lebih tua untuk bersilaturahmi

70 Ciri khas masyarakat pedesaan, yaitu memiliki sifat guyub yang tinggi

71 Menitipkan anak kepada paman atau bibi adalah hal yang lumrah bagi masyarakat Sunda

72 Suku sunda memiliki pengetahuan tentang pengelolaan lingkungan yang harmonis dan selaras. Falsafah pengelolaan alam ini dikenal dengan sebutan sunda wiwitan. Sunda wiwitan adalah sistem ajaran pengelolaan lingkungan yang ada di tanah sunda sejak dahulu. Dalam cerpen berjudul Mencari dijumpai warna lokal sunda berupa deskripsi lingkungan khas daerah yang didiami oleh suku sunda yang asri dan terjaga. $d i$

\section{Kuburan}

Mencari

Kekeluargaan

Harapan Kekeluargaan

mencari lingkungan

\section{Simpulan}

Hasil penelitian dapat disimpulkan bahwa warna lokal sunda yang muncul dalam kumpulan cerpen Dua Orang Dukun dan Cerita Pendek Sunda Lainnya yang dideskripsikan dan dianalisis sesuai dengan lima sikap warna lokal sunda, yakni religius, kepribadian, sosial, kekeluargaan, dan lingkungan.

Penelitian ini dapat mendeskripsikan nilai-nilai karakter yang muncul dalam kumpulan cerpen Dua Orang Dukun dan Cerita Pendek Sunda Lainnya.

Penelitian ini sudah menjawab pertanyaan penelitian, akan tetapi karena penelitian ini merupakan jenis penelitian kualitatif, maka peneliti dalam penentuan data penelitian akan dilakukan terus menerus sepanjang penelitian, dalam hal ini tujuan sampling akan mencakup sebanyak mungkin informasi yang bersifat holistik kontekstual. Berdasarkan hal tersebut, peneliti akan sangat terbuka menerima saran dari berbagai pihak untuk penyempurnaan penelitian ini dimasa yang akan datang.

\section{Daftar Pustaka}

Aminuddin. 2013. Pengantar Apresiasi karya Sastra. Bandung: Sinar Baru Algesindo.

A Teeuw. 2015. Sastra dan Ilmu Sastra. Bandung: Dunia Pustaka Jaya.

Rozak, Abdul dan Sobihah Rasyad. 2016. Pembelajaran Sastra Berbasis Teks. Yogyakarta: Frame Publishing.

Sardjono, Agus. 2004. Pengetahuan Tradisional. Jakarta: Universitas Indonesia

Saryono, Djoko. 2009. Dasar apresiasi Sastra. Yogyakarta: Elmathera Publishing.

Semi, M. Atar. 2012. Metode Penelitian Sastra. Bandung: Penerbit Angkasa.

Sugiyono. 2011. Metode Penelitian Kualitatif, Kuantitatif, Dan R\&D. Bandung: Alfabeta. 